Available online on 15.02.2020 at http://jddtonline.info
Open Access to Pharmaceutical and Medical Research
undestricted non-commercial use, provided the original work is properly cited

Open $\odot$ Access

Review Article

\title{
Medical Perspective on Ama as per Ayurveda and Modern Consideration: A Review
}

\section{Parag Vasudev Yadav}

M.D. (Rognidan Avam Vikriti vidnyan) Assistant Professor, MES Ayurved Mahavidyala, Ghanekhunt Lote, Taluka - Khed, District-Ratnagiri, Maharashtra, India

\begin{abstract}
The Ayurveda mainly focuses to maintaining health status by preventing and treating diseases. The prevention and treatment of diseases only possible when physician aware about biochemical events and pathogenesis of disease. The knowledge about causative factors of disease helps to prevent disease prevalence and Ama is one such pathological factor that causes many diseases like; Grahani Roga, allergy and Amavata, etc. The ancient philosopher of Ayurveda described concept of Ama as biological entity responsible for many pathological events inside the body. Ama is considered as toxins produced due to the improper functioning of Agni therefore Ama can be considered as unripe or un-metabolized food material. Ama vitiates Doshas and disturbs Dhatu-samya, after combining with Dosha and mala Ama initiate pathogenesis of diseases. Present article summarizes Ayurveda and modern perspective related to Ama and its role in disease pathogenesis.
\end{abstract}

Keywords: Ayurveda, Ama, Toxins, Amavata, Auto-immune.

Article Info: Received 19 Nov 2019; $\quad$ Review Completed 21 Jan 2020; $\quad$ Accepted 27 Jan 2020; $\quad$ Available online 15 Feb 2020

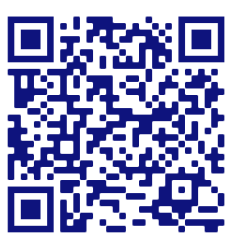

Cite this article as:

Yadav PV, Medical Perspective on Ama as per Ayurveda and Modern Consideration: A Review, Journal of Drug Delivery and Therapeutics. 2020; 10(1-s):205-207 http://dx.doi.org/10.22270/jddt.v10i1-s.3861

*Address for Correspondence:

Dr Parag Vasudev Yadav, M.D. (Rognidan Avam Vikriti vidnyan) Assistant Professor, MES Ayurved Mahavidyala, Ghanekhunt Lote, Taluka - Khed, District-Ratnagiri, Maharashtra, India

\section{Introduction}

Ayurveda science elaborated different concepts related to disease pathogenesis and Ama is one of them described as toxins or antigen which can trigger diseases pathogenesis. It is believed that hypo-functioning of Agni leads production of Ama which can combine with other biological entities and induces various pathological conditions as mentioned below:

\section{$\checkmark$ Ama with Vata \& Pitta induces condition of Sama Dosha \\ $\checkmark$ Ama with Dhatus induces condition of Sama Dushya \\ $\checkmark \quad$ Ama with Mala induces Sama Mala}

The above mentioned combinations of Ama with Doshas, Dhatus and Malas resulted diseases like; Amajeerna, Atisara, Grahani Dosha, Jwara and Amavata, etc 1-4.

When Ama mixes with Vata then it aggravates in lower abdominal and disturbs functioning of colon and Joints. The symptoms of Vata ama are dry mouth, astringent taste, constipation, dry skin, bloating, pain and arthritis.
When Ama mixes with Pitta Dosha then it accumulate at middle abdominal and affects functioning of small intestine and liver. Pitta ama circulates with blood, sour and acidic in nature and imparts bitter taste in mouth. This conditions causes heartburn, diarrhea, nausea and acid indigestion 2-6.

When Kapha mixes with Ama then it accumulate in stomach and chest, Kapha Ama possess foul smelling, create a salty taste in mouth, suppress appetite, sinus congestion and and tenderness.

Disturbed dietary habits, improper sleeping pattern, unethical conduct, excessive sexual indulgence, day time sleep and lack of disciplinary living regimen, etc. are some factors which can leads Agnimandya followed by production of Ama. Ama generally affects Tridoshas, Dhatus and Malas by combining with them and causes diseases. General events related to pathological consequences of Ama depicted in Figure 1 


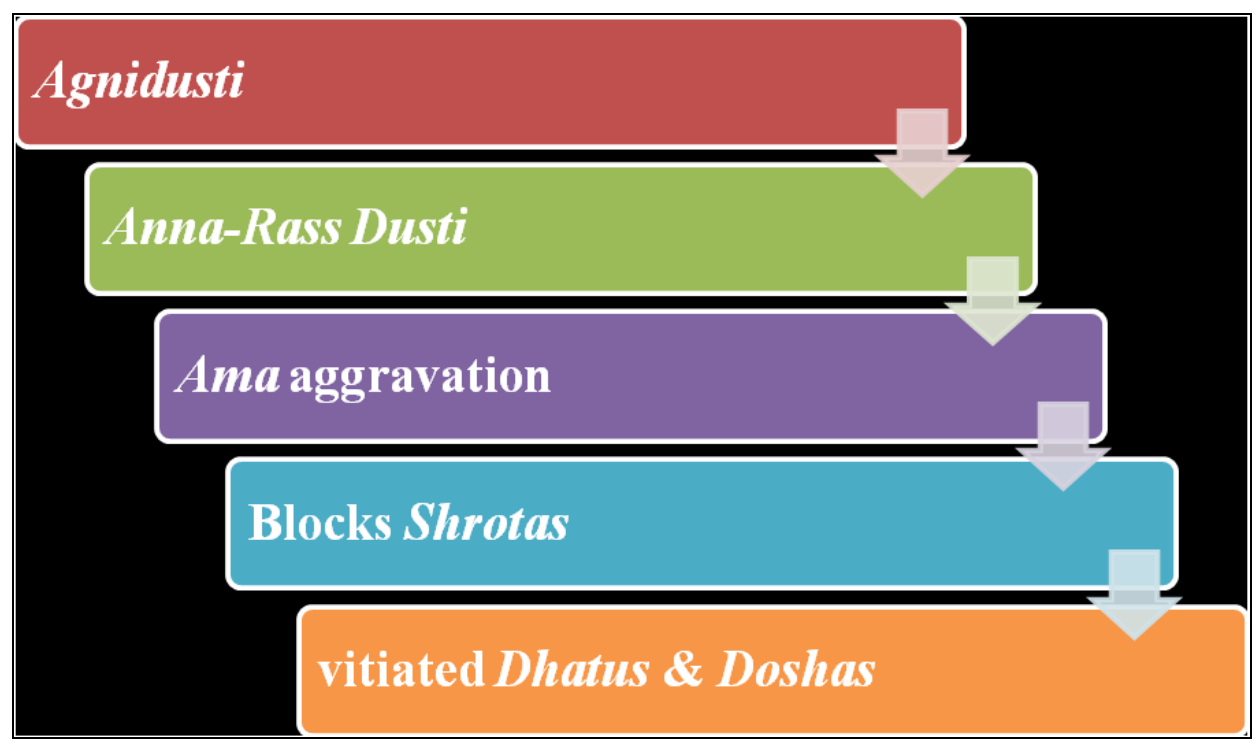

Figure 1: General pathological events related to Ama.

The various pathological factors (Samprapti-Ghatak) associated with Ama are as follows:

$\begin{array}{lll}\text { * Hetu: } & \text { Agnidusti, Agnimandhkarak } \\ \text { * Adisthan: } & \text { Mahasrotas, Viseshta Grahani } \\ \text { * Dosa: } & \text { Tridosa } \\ \text { * Srotas: } & \text { Annavah, Purisvah } \\ \text { * Dusya: } & \text { Anna, Ras }\end{array}$

The Ama produced by low level of Jatharagni and Bhutaagni possess heavy and sticky nature therefore blocks channels of body. The Ama when combined with Doshas termed as Amavisha which can causes chronic illness. The pathological events associated with Ama are as follows:

- Blocks minute channels thus affect circulatory process

- $\quad$ Ama aggravates Tridosha

- Disturbs nutritional supply to the tissue

- $\quad$ Diminishes potency of Dhatus
- Vitiate Agni and imparts feeling of uneasiness

- Causes lethargy, mental sickness and lack of enthusiasm

- Gas, diarrhea, bloating, bad smelling mouth and loss of appetite

$$
\begin{aligned}
& \text { Characteristics of } \mathbf{A m a} \\
& \text { * Unpleasant odour } \\
& \text { * Deprives nutritional components of Ahara } \\
& \text { * Possess tendency of accumulation } \\
& \text { * Heavy and Sticky }
\end{aligned}
$$

Different combination of Ama with Doshas and their pathological manifestations:

Ama obstructs Srotas of body and can combine with Doshas to produces various diseases as follows mentioned in Table 1

Table 1: Ama towards disease pathogenesis

\begin{tabular}{|c|c|c|}
\hline S. N. & Diseases & Doshas predominance \\
\hline 1 & Visuchika & Kapha \\
2 & Vilambika, Atisara & Pitta \\
3 & Alasaka, Amavata, Shotha & Vata \\
\hline
\end{tabular}

\section{Modern perspective of $\mathrm{Ama}$ as toxins and autoimmune diseases}

Autoimmune diseases occur due to the harmful response of self immune system when immune system stated attacking of body tissue as anticipated response against antigen/toxins or Ama. The inflammatory response occurs in autoimmune disorders triggered by Ama or antigen at cellular level.
Antigen vitiated Dosha, altered immune response which further damages tissues. Antigen/ Ama modulate signaling at cellular levels leading to incompatible autoimmune response that damage tissues. Ankylosing spondylitis, crohn's disease, psoriasis, rheumatoid artritis, ulcerative colitis and lupus erythematodes, etc. can be considered as autoimmune diseases arises as response against Ama or antigen 6-8. 


\section{Ayurveda management of Ama Doshas}

Nidan Parivarjanan means avoidance of causative factors helps to prevent harmful effects of Ama. Overeating should be avoided and food cooked properly need to be consumed Hot, sour, heavy and oily food stuffs not recommended. Psychological stress can suppress Agni therefore should remain away from stress, anxiety, anger and grief. Ama Pachan substances recommended depending upon the Prakriti of an individual. Agni Dipana herbs, Shodhan therapy, Swedana therapy, Snehana and Yoga helps to eliminate Ama and vitiate Doshas.

Herbs which digest Vata like; Trikatu, Ginger, Black Pepper, Cinnamon, Hing, Ajwan and Fennel, etc. helps to softening accumulate Ama and eliminate aggravated Vata Dosha.

Similarly Pitta Ama can be pacified by using bitter herbs, spices, coriander, cinnamon and lime. The detoxification measures also help to remove Pitta Ama.

Kapha Ama can be corrected using expectorants \& emetics drugs. Pungent and bitter herbs help to pacify Kapha Ama. Trikatu, Ginger, Pippali, Chitrak, Garlic, Vidanga and Tulsi, etc. helps to correct Kapha Ama.

\section{Pathya}

$>$ Sour fruits \& vegetables

$>$ Whole grains \& mung beans

$>$ Spices, ginger, cinnamon and fennel

$>$ Pumpkin seeds, mustard oil and flax seed oil

\section{Apathya}

$>$ Sweet, sour and salty stuffs

$>$ Mushrooms, nuts and dairy products

$>$ Processed and starchy grains
$>$ Red meat and shellfish

\section{Conclusion}

Ama formed at the levels of Jatharagni and Dhatvagni and initiated many pathological events inside the body. Ama further deteriorates digestive and metabolic activities, blocks Strotas, vitiated Dhatus and Rakta therefore causes various diseases including auto-immune disorders. Avoidance of Virrudha Aahara, fear, anxiety, restoring disciplinary daily regimen, Ayurveda drugs, detoxification measures, Yoga and considerations of concept of Pathya and Apathya helps to avoid prevalence of diseases associated with excessive production of Ama.

\section{References}

1. Dwarikanath C., Introduction to Kayachikitsa, Chaukhanbha Orientalia, Varanasi, third edition, 1996; Page no. 69.

2. Gaur B. L., Astanga Hridyama, Samvartika Hindi commentary, Chaukhanbha Orientalia,Varanasi,Reprint edition., 2013; Sutra sthana13/23-24.

3. Vagbhata, Ashtanga Hridayam, NidanaSthana, Vatashonita Adhyaya, 16/1-4, In: Kaviraja Atrideva Gupta (ed), 2012, Chaukhamba Prakashana, Varanasi, p: 381.

4. Shastri K.N; Chaturvedi G.N; Charak samhita 8 ed. Chaukhambha bharti academy, Varanasi 1981.

5. Alpesh P Sorathiya, Vyas SN, Bhat P.S.N, A Clinical Study son the Role of Ama in Relation to Grahani Roga and its Management by Kalingadi Ghanavati and Tryushnadi Ghrita, Ayu, 2010; 31(4):451-5.

6. Singh R.H; Ayurveda Nidana Chikitsa Siddhant, Chaukhambha Amar Bharti Prakashan Varanasi 1983.

7. Chawardol Seema G., Sapan B, Ayurvedic Line of Treatment of Allergic Rhinitis (Vatakaphaja Pratishaya), International Journal of Ayurvedic \& Herbal Medicine, 2014; 4(4):1427-1531.

8. Gaikwad PP, Rohini S, Jain AK, Ama with Special Reference to Nidanpanchakatmak View of Amavata (Rheumatoid Arthritis) and Rheumatoid Factor, JIPBS, 2015; 2 (4):478-481. 